\title{
Możliwość zastosowania wymiaru fraktalnego do określania ksztaltu kryształów na przykładzie wybranych minerałów skałotwórczych intruzji Monczegorska (NE Fennoskandia)
}

\author{
Miłosz Huber ${ }^{1}$
}



The possibility of using a fractal dimension to determine the shape of crystals - a case study on selected rock-forming minerals from the Monchepluton intrusion (NE Fennoscandia). Prz. Geol., 69: 434-442; doi: $10.7306 / 2021.27$

A b s tra c t. A petrographic description of olivine, ortho-, clinopyroxene, and plagioclase was obtained for rocks derived from a Paleoproterozoic layered intrusion of the Monchepluton. Based on these results, calculations were made of the fractal box dimension, which determines the degree of development of the boundaries of these minerals. After the calculations, they were illustrated on maps showing the correlation of this coefficient with the location of the sample in the field. These results were then correlated with petrographic observations. Based on this method, the analogies between the result of the fractal dimension and the petrographic description of rock-forming minerals were assessed. The data show that such an analogy to a limited extent may be a significant indicator for the interpretation of the results. The use of this method is not universal and strictly depends on the mineral association and the knowledge obtained by classic petrographic studies.

Keywords: Fractal dimension, rock-forming minerals, Monchepluton, NE Fennoscandia

Pluton Monczegorska (ryc. 1) jest paleoproterozoiczną, warstwowaną intruzją na półwyspie Kola w NE części tarczy fennoskandzkiej (Mitrofanov, 2000; Sharkov, 2006; Huber, 2021). Intruzja ta składa się z dwóch ramionjednego o kierunku w przybliżeniu południkowym, a drugiego o przebiegu równoleżnikowym. W ramieniu południkowym znajdują się 3 masywy (od południa) Nittis, Kumuzhia i Traviannaya (NKT), a w równoleżnikowym (od zachodu) Sopcha, Nyud oraz Poaz. Masywy NKT składają się z dunitów i harzburgitów, którym towarzyszą chromityty oraz ortopiroksenity. W masywie Sopcha występują ortopiroksenity i podrzędnie oliwinowe ortopiroksenity, a w Nyud i Poaz - noryty i gabronoryty (ryc. 1). Wiek intruzji jest oceniany na 2,5 mld lat (Pozhylienko $\mathrm{i}$ in., 2002; Bayanova, 2004; Bayanova i in., 2019). Skały tego masywu powstały w wyniku wieloetapowej krystalizacji minerałów, której towarzyszyły iniekcje magmy (Hałas i in., 2009; Huber i in., 2012; Lubnina i in., 2016; Rundkvist $i$ in., 2018). Po okresie krystalizacji nastąpiły liczne procesy wtórne, w tym także lokalny metamorfizm (Arzamastsev i in., 2009; Baluev i in., 2009; Baltybayev, 2013), powodujące widoczne zmiany teksturalne w skałach. Minerały skałotwórcze w skałach intruzji Monczegorska, takie jak pirokseny, oliwiny i plagioklazy, krystalizowały w różnych warunkach, niektóre z nich noszą ślady korozji. Zróżnicowany kształt tych minerałów odzwierciedla procesy, jakie zachodziły w skałach. Precyzyjne prześledzenie kształtu minerałów intruzji może posłużyć do określenia stopnia zaawansowania procesów wtórnych.

Celem niniejszego artykułu jest precyzyjne określenie kształtu wybranych minerałów skałotwórczych intruzji Monczegorska oraz ich interpretacja petrograficzna. Badania wykonano za pomocą analizy fraktalnej (Petigen i in., 1992; Miyashiro, 1994; Huber, 2012).
Analiza fraktalna jest stosunkowo szybko rozwijająca się metodą badawczą. W geologii jest zwykle stosowana do oceny porowatości skał, badania ziarnistości gleb (Gulbin, Evabgulova, 2003; Lehmann i in., 2003; Martin, Reyes, 2008; Kincal i in., 2010; Chen i in., 2021), analiz geofizycznych i złożowych (Mohammadi i in., 2013; Zhengli i in., 2014), tektonicznych (Słaby i in., 2014) oraz badania teksturalnego skał (Voitsekhovsky i in., 1997; Zheru i in., 2001; Gerig i in., 2010; Singh i in., 2021).

\section{METODYKA}

Do badań wybrano 36 próbek skał występujących w intruzji Monczegorska (ryc. 1, tab. 1) i wykonano z nich płytki cienkie. Preparaty te udokumentowano mikrofotograficznie z użyciem optycznego mikroskopu polaryzacyjnego Leica DM2500P i określono ich skład petrograficzny. W celu przeprowadzenia analizy fraktalnej na mikrofotografiach tych wytypowano do obserwacji 231 ziaren minerałów skałotwórczych - oliwinów, ortopiroksenów, klinopiroksenów i plagioklazów. Na ziarna te kilkakrotnie nałożono siatkę kwadratową o różnych wymiarach boku (np. 36, 72 i 144 pikseli). Następnie zliczano liczbę kwadratów, przez które przechodziła granica badanego ziarna minerału i korzystając ze wzoru [1] wg Petigena i in. (1992), wyliczano jego wymiar fraktalny:

$$
D=\frac{\left(\log x_{2}-\log x_{1}\right)}{\left(\log d_{2}-\log d_{1}\right)}
$$

gdzie:

$x_{1}$ oraz $x_{2}-$ liczba kwadratów w konturze ziarna minerału, zliczona po zastosowaniu siatek kwadratowych o długości boku $d_{1}$ i $d_{2}$.

\footnotetext{
${ }^{1}$ Wydział Nauk o Ziemi i Gospodarki Przestrzennej, Uniwersytet Marii Curie-Skłodowskiej, Al. Kraśnickie 2d/107, 20-718 Lublin; mhuber@umcs.pl milosz.huber@mail.umcs.pl
} 




Ryc. 1. Szkic geologiczny intruzji Monczegorska (wg Mitrofanov, Smolkin, 2004, uproszczony) z lokalizacją poboru próbek skał Ryc. 1. Geological sketch of the Monchepluton (according to Mitrofanov, Smolkin, 2004, simplified) showing the sampling location

Tab. 1. Lokalizacja próbek skał pobranych z intruzji Monczegorska do analizy fraktalnej

Table 1. Location of rock samples taken from the Monchepluton for fractal analysis

\begin{tabular}{|c|c|c|c|c|c|c|c|}
\hline $\begin{array}{c}\text { Próbka } \\
\text { Sample }\end{array}$ & $\begin{array}{l}\text { Masyw } \\
\text { Massif }\end{array}$ & $\begin{array}{c}\text { Szerokość } \\
\text { geograficzna } \\
\text { Latitude }\end{array}$ & $\begin{array}{c}\text { Dlugość } \\
\text { geograficzna } \\
\text { Longitude }\end{array}$ & $\begin{array}{l}\text { Próbka } \\
\text { Sample }\end{array}$ & $\begin{array}{l}\text { Masyw } \\
\text { Massif }\end{array}$ & $\begin{array}{c}\text { Szerokość } \\
\text { geograficzna } \\
\text { Latitude }\end{array}$ & $\begin{array}{c}\text { Dlugość } \\
\text { geograficzna } \\
\text { Longitude }\end{array}$ \\
\hline 1 & \multirow{6}{*}{ Traviannaya } & $67^{\circ} 56^{\prime} 40.5^{\prime \prime} \mathrm{N}$ & $32^{\circ} 48^{\prime} 52.6^{\prime \prime} \mathrm{E}$ & 19 & \multirow{7}{*}{ Sopcha } & $67^{\circ} 53^{\prime} 49.5^{\prime \prime} \mathrm{N}$ & $32^{\circ} 49^{\prime} 54.6^{\prime \prime} \mathrm{E}$ \\
\hline 2 & & $67^{\circ} 56^{\prime} 32.4^{\prime \prime} \mathrm{N}$ & $32^{\circ} 48^{\prime} 08.3^{\prime \prime} \mathrm{E}$ & 20 & & $67^{\circ} 53^{\prime} 36.31^{\prime \prime} \mathrm{N}$ & $32^{\circ} 48^{\prime} 53.35^{\prime \prime} \mathrm{E}$ \\
\hline 3 & & $67^{\circ} 56^{\prime} 32.4^{\prime \prime} \mathrm{N}$ & $32^{\circ} 48^{\prime} 08.3^{\prime \prime} \mathrm{E}$ & 21 & & $67^{\circ} 54^{\prime} 05,95{ }^{\prime \prime} \mathrm{N}$ & $32^{\circ} 51^{\prime} 23,29^{\prime \prime} \mathrm{E}$ \\
\hline 4 & & $67^{\circ} 56^{\prime} 36.3^{\prime \prime} \mathrm{N}$ & $32^{\circ} 49^{\prime} 09.3^{\prime \prime} \mathrm{E}$ & 22 & & $67^{\circ} 53^{\prime} 41.7^{\prime \prime} \mathrm{N}$ & $32^{\circ} 51^{\prime} 17.2^{\prime \prime} \mathrm{E}$ \\
\hline 5 & & $67^{\circ} 56^{\prime} 33.0^{\prime \prime} \mathrm{N}$ & $32^{\circ} 49^{\prime} 03.3^{\prime \prime} \mathrm{E}$ & 23 & & $67^{\circ} 53^{\prime} 23.3^{\prime \prime} \mathrm{N}$ & $32^{\circ} 52^{\prime} 05.1^{\prime \prime} \mathrm{E}$ \\
\hline 6 & & $67^{\circ} 56^{\prime} 38.2^{\prime \prime} \mathrm{N}$ & $32^{\circ} 48^{\prime} 40.2^{\prime \prime} \mathrm{E}$ & 24 & & $67^{\circ} 53^{\prime} 09.2^{\prime \prime} \mathrm{N}$ & $32^{\circ} 52^{\prime} 48.6^{\prime \prime} \mathrm{E}$ \\
\hline 7 & \multirow{3}{*}{ Kumuzhia } & $67^{\circ} 55^{\prime} 45,55^{\prime \prime} \mathrm{N}$ & $32^{\circ} 47^{\prime} 29.51^{\prime \prime} \mathrm{E}$ & 25 & & $67^{\circ} 53^{\prime} 09.2^{\prime \prime} \mathrm{N}$ & $32^{\circ} 52^{\prime} 48.6^{\prime \prime} \mathrm{E}$ \\
\hline 8 & & $67^{\circ} 55^{\prime} 50.88^{\prime \prime} \mathrm{N}$ & $32^{\circ} 47^{\prime} 26.16^{\prime \prime} \mathrm{E}$ & 26 & \multirow{2}{*}{$\begin{array}{l}\text { anomalia Nyud } \\
\text { Nyud anomaly }\end{array}$} & $67^{\circ} 53^{\prime} 37.4^{\prime \prime} \mathrm{N}$ & $32^{\circ} 53^{\prime} 01.4$ ”'E \\
\hline 9 & & $67^{\circ} 55^{\prime} 44.3^{\prime \prime} \mathrm{N}$ & $32^{\circ} 48^{\prime} 03.9{ }^{\prime \prime} \mathrm{E}$ & 27 & & $67^{\circ} 53^{\prime} 03.2^{\prime \prime} \mathrm{N}$ & $32^{\circ} 52^{\prime} 58.3^{\prime \prime} \mathrm{E}$ \\
\hline 10 & \multirow{2}{*}{ Nittis } & $67^{\circ} 55^{\prime} 05.48^{\prime \prime} \mathrm{N}$ & $32^{\circ} 45^{\prime} 32.88^{\prime \prime} \mathrm{E}$ & 28 & \multirow{6}{*}{ Nyud } & $67^{\circ} 53 ’ 11.3 ” \mathrm{~N}$ & $32^{\circ} 53^{\prime} 57.3^{\prime \prime} \mathrm{E}$ \\
\hline 11 & & $67^{\circ} 54^{\prime} 51.4^{\prime \prime} \mathrm{N}$ & $32^{\circ} 45^{\prime} 27.2^{\prime \prime} \mathrm{E}$ & 29 & & $67^{\circ} 53^{\prime} 11.3 ” \mathrm{~N}$ & $32^{\circ} 53^{\prime} 57.3^{\prime \prime} \mathrm{E}$ \\
\hline 12 & \multirow{4}{*}{$\begin{array}{l}\text { blok dunitowy } \\
\text { Dunite Block }\end{array}$} & $67^{\circ} 53^{\prime} 57.4^{\prime \prime} \mathrm{N}$ & $32^{\circ} 45^{\prime} 59.0$ 'E & 30 & & $67^{\circ} 53 ’ 29.2^{\prime \prime} \mathrm{N}$ & $32^{\circ} 54^{\prime} 48.1^{\prime \prime} \mathrm{E}$ \\
\hline 13 & & $67^{\circ} 53^{\prime} 57.4^{\prime \prime} \mathrm{N}$ & $32^{\circ} 45^{\prime} 59.0^{\prime \prime} \mathrm{E}$ & 31 & & $67^{\circ} 53^{\prime} 31.7^{\prime \prime N}$ & $32^{\circ} 54^{\prime} 55.7^{\prime \prime} \mathrm{E}$ \\
\hline 14 & & $67^{\circ} 53^{\prime} 57.4^{\prime \prime} \mathrm{N}$ & $32^{\circ} 45^{\prime} 59.0^{\prime \prime} \mathrm{E}$ & 32 & & $67^{\circ} 53^{\prime} 38.3^{\prime \prime} \mathrm{N}$ & $32^{\circ} 55^{\prime} 21.1$ '”E \\
\hline 15 & & $67^{\circ} 53^{\prime} 49.09 ” \mathrm{~N}$ & $32^{\circ} 44^{\prime} 57.01^{\prime \prime} \mathrm{E}$ & 33 & & $67^{\circ} 53^{\prime} 38.2^{\prime \prime} \mathrm{N}$ & $32^{\circ} 55^{\prime} 22.4^{\prime \prime} \mathrm{E}$ \\
\hline 16 & \multirow{3}{*}{ Sopcha } & $67^{\circ} 53^{\prime} 29.7^{\prime \prime} \mathrm{N}$ & $32^{\circ} 49^{\prime} 59.1{ }^{\prime \prime} \mathrm{E}$ & 34 & \multirow{2}{*}{ Poaz } & $67^{\circ} 54^{\prime} 58.5^{\prime \prime} \mathrm{N}$ & $32^{\circ} 58^{\prime} 36.0^{\prime \prime} \mathrm{E}$ \\
\hline 17 & & $67^{\circ} 53^{\prime} 33.7^{\prime \prime} \mathrm{N}$ & $32^{\circ} 50^{\prime} 03.4^{\prime \prime} \mathrm{E}$ & 35 & & $67^{\circ} 54^{\prime} 56.5^{\prime \prime} \mathrm{N}$ & $32^{\circ} 58^{\prime} 20.5^{\prime \prime} \mathrm{E}$ \\
\hline 18 & & $67^{\circ} 53^{\prime} 40.5^{\prime \prime} \mathrm{N}$ & $32^{\circ} 50^{\prime} 11.0^{\prime \prime} \mathrm{E}$ & 36 & Vurechuaivench & $67^{\circ} 52^{\prime} 38.1^{\prime \prime} \mathrm{N}$ & $32^{\circ} 00^{\prime} 49.0^{\prime \prime} \mathrm{E}$ \\
\hline
\end{tabular}




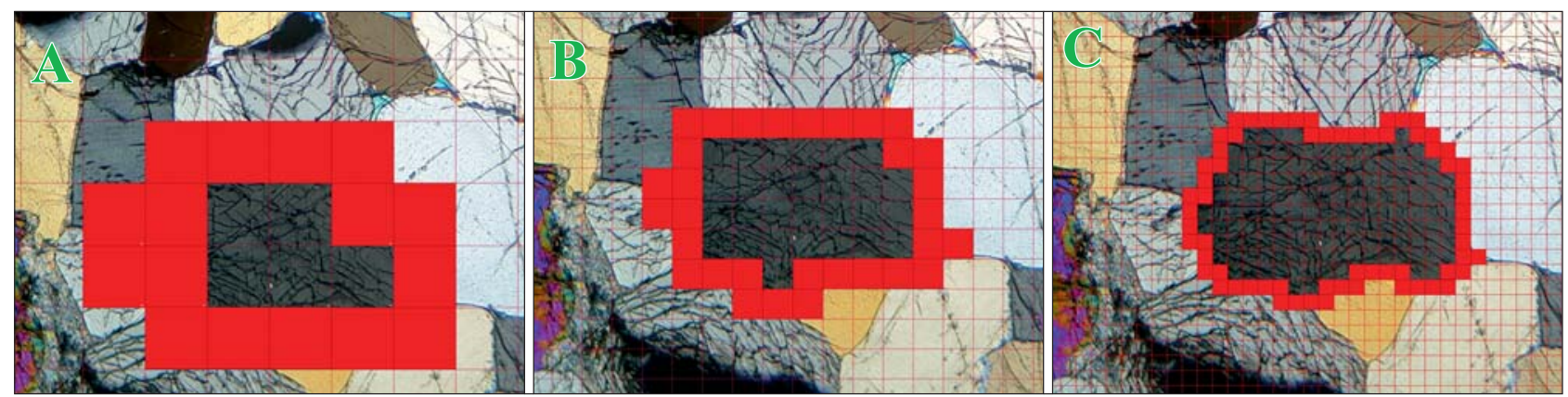

Ryc. 2. Przykłady zliczania liczby kwadratów w konturze ziarna minerału z zastosowaniem siatek o różnej długości boku Ryc. 2. Examples of counting the number of squares in a mineral grain contour using grids with different side lengths

\section{$\rightarrow$}

Ryc. 3. Wymiary fraktalne przykładowych figur obliczone wg wzoru [1]

Ryc. 3. Examples of selected contours and their fractal dimension, calculated according to formula [1]

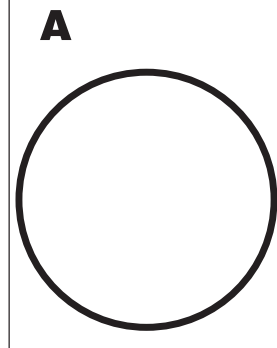

1,37
B

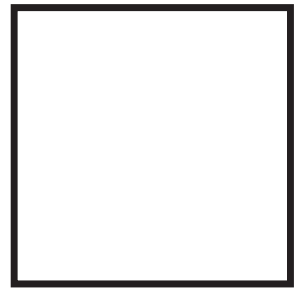

1,40



Stosując wzór [1], powtarzano obliczenia z różnymi wielkościami siatki (ryc. 2). Po uśrednieniu wyników obliczono wymiar fraktalny pudełkowy 92 ziaren minerałów skałotwórczych skał intruzji Manczegorska wybranych z 33 próbek skał (tab. 2).

Wymiar fraktalny pudełkowy jest wyrażany w formie liczbowej i zależy od skomlikowania kształtu krawędzi badanego obiektu (ryc. 3). Wymiar ten nie jest natomiast zależny od kierunku, w jakim zmienia się kształt.

\section{WYNIKI}

\section{Skały intruzji Monczegorska}

Dunit (próbka 13) występuje głównie w bloku dunitowym (ryc. 4A), gdzie przeławica się z chromitytem, tworząc zwarty, warstwowany kompleks skalny. Skała ta składa się z dużych, obłych, stykających się ze sobą kryształów oliwinu, pomiędzy którymi znajdują się ziarna chromitu. W interstycjach pomiędzy tymi minerałami są widoczne niekiedy niewielkie ilości serpentynu i talku. W próbce 13 pomiędzy oliwinami znajduje się niewielkie ziarno ortopiroksenu.

Chromityt składa się głównie ze zbliźniaczonych chromitów (próbka 12), tworzących nagromadzenia stykających się ze sobą kryształów, pomiędzy którymi występują oliwiny i ortopirokseny. Oliwiny są mocno zserpentynizowane. Współwystępują z nimi talk oraz węglany. W skale są widoczne nagromadzenia minerałów maficznych, które podkreślają warstwowaną teksturę skały.

Oliwinowy gabronoryt rozpoznano w strefie kontaktowej bloku dunitowego (próbka 15). Jego tło skalne stanowią plagioklazy o strukturze ofitowej. Minerały te tworzą polisyntetyczne zbliźniaczenia. Ich kształt jest zróżnicowany i wskazuje na wtórną krystalizację w przestrzeni pomiędzy minerałami melanokratycznymi. Ortokumulat jest reprezentowany przez oliwiny, noszące często ślady daleko posuniętej korozji i otoczone koronami reakcyjnymi, składającymi się z chlorytów, serpentynu i talku. Obok oliwinów są widoczne kryształy ortopiroksenów, które mają dominujący udział w grupie minerałów maficznych. Minerały te tworzą nagromadzenia stykających się ze sobą osobników, a miejscami noszą ślady korozji, widoczne w formie zatok. W interstycjach pomiędzy ortopiroksenami wykrystalizowały ziarna klinopiroksenu o silnie rozbudowanym kształcie. W skale dostrzega się także żyłki talku. Minerały rudne występują zwykle w postaci niewielkich wpryśnięć magnetytu w sąsiedztwie oliwinu.

Harzburgit odsłania się w masywie Kumuzhia, a także w masywach Sopcha i Nyud (próbki 16, 21, 22, 25 i 31). Tło skalne tworzą w nim oliwiny i ortopirokseny z domieszką chromitu oraz siarczków. Ortopirokseny mają duże kryształy, w strefach granicznych często zserpentynizowane (ryc. 4B). Obok nich jest widoczny oliwin, zwykle zdeformowany. W strefach serpentynizacji podrzędnie występuje klinopiroksen oraz tytanit, nieliczne plagioklazy i flogopit. W odmianach oliwinowych (próbka 9) obok ortopiroksenu, tworzącego duże, ksenomorficzne kryształy (osiągające kilka mm długości), występuje oliwin. Znajduje się on w skale w dużych ilościach. Towarzyszą mu talk, chromit, klinopiroksen, serpentyn oraz tytanit. W harzburgicie z masywu Nyud stwierdzono także ilmenit i biotyt.

Plagioharzburgit występuje w bloku dunitowym, na zachodnich stokach masywu Traviannaya oraz w masywie Nyud (próbki 2, 14 oraz 29). Skała ta składa się z oliwinów, które wykazują deformacje sieciowe (objawiające się anomalnym ściemnianiem falistym), oraz pojedynczych blaszek flogopitu, wciśniętych pomiędzy oliwiny a ortopirokseny. Ortopirokseny o obłych ziarnach, stykających się ze sobą, mają znaczący udział wśród składników maficznych tej skały. W interstycjach pomiędzy ortopiroksenami można dostrzec pojedyncze, nieregularne ziarna plagioklazów, wciśnięte w tło skalne. W skale są widoczne także klinopirokseny oraz pojedyncze minerały rudne (np. chromit). 
Oliwinowy plagiowebsteryt odsłania się w masywie Traviannaya (próbki 3 oraz 6). Skała ta składa się z grubokrystalicznych ortopiroksenów, którym towarzyszą oliwin i klinopirokseny. Niektóre kryształy ortopiroksenu są zdeformowane. Kryształy oliwinu są zwykle zserpentynizowane i mają wrostki magnetytu oraz flogopitu. Towarzyszy im chromit w postaci pojedynczych kryształków ulokowanych w sąsiedztwie oliwinów. Klinopirokseny wykrystali- zowały w przestrzeniach pomiędzy ortopiroksenami i mają nieregularny kształt. W skale tej występują siarczki, a gdzieniegdzie w otoczeniu minerałów maficznych - plagioklazy.

Masywny ortopiroksenit rozpoznano we wschodniej części masywu Traviannaya, a także w masywach Nittis i Sopcha (próbki 4, 5, 17 oraz 20). Skała ta zawiera ortopirokseny i towarzyszące im akcesorycznie siarczki, klino-



Ryc. 4. Zdjęcia mikroskopowe skał intruzji Monchegorska: A - dunit, B - harzburgit, C - ortopiroksenit, D - noryt, E - gabronoryt, $\mathbf{F}$ - zamfibolityzowany gabronoryt: chr - chromit, $\mathbf{c p x}$ - klinopiroksen, hbl - hornblenda zwyczajna, ol - oligoklaz, opx - ortopiroksen, srp - serpentyn, tlc - talk, tr - tremolit

Ryc. 4. Typical rocks from the Monchepluton: $\mathbf{A}$ - dunite, $\mathbf{B}$ - harzburgite, $\mathbf{C}$ - orthopyroxenite, $\mathbf{D}$ - norite, $\mathbf{E}$ - gabbronorite, $\mathbf{F}$ amphibolised gabbronorite: $\mathbf{c h r}$ - chromite, $\mathbf{c p x}$ - clinopyroxene, hbl - common hornblende, ol - oligoclase, opx - orthopyroxene, $\mathbf{s r p}$ - serpentine, tlc - talc, tr - tremolite 
pirokseny, a także minerały wtórne: aktynolit, tremolit, talk i magnetyt (ryc. 4C). Ortopirokseny są zwykle wykształcone w formie obłych ziaren, ściśle stykających się ze sobą (ryc. 4C). Niekiedy towarzyszy im chromit. Gdzieniegdzie są obecne pooliwinowe pseudomorfozy minerałów z grupy serpentynu oraz aktynolitu, tremolitu, epidotu i talku. W masywie Nittis oraz na północnych stokach Sopcha występują odmiany plagioortopiroksenitów (próbka 11), w których pomiędzy kryształami ortopiroksenu można dostrzec niewielkie ziarma plagioklazu.

Oliwinowy ortopiroksenit występuje w masywach Nittis, Kumuzhia oraz na zachodnich stokach masywu Sopcha (próbki 1, 7, 10, 18, 19 i 23). Głównym budulcem tej skały są ortopirokseny. Ich kryształy ściśle stykają się ze sobą. Pomiędzy nimi występują pojedyncze ziarna oliwinu. W masywie Sopcha oliwiny noszą ślady silnych procesów wtórnych, są mocno zserpentynizowane, z widocznym talkiem oraz flogopitem. W masywie Nittis w skale tej można niekiedy dostrzec bardzo niewielkie kryształki plagioklazów, zwykle wciśnięte pomiędzy kryształy ortopiroksenów. W miejscach, gdzie plagioklazy stykają się z oliwinami, są widoczne korony reakcyjne utworzone z chlorytu, talku (który występuje także w strefie spękań) i flogopitu. W strefach tektonicznych w masywie Kumuzhia stwierdzono także brekcję oliwinowego piroksenitu (próbka 8). Obok ortopiroksenów i oliwinu występują w niej także chromit i diopsyd. Oliwiny cechują się różnym stopniem zserpentynizowania. Towarzyszą im talk, węglany oraz tlenki i wodorotlenki żelaza. Okruchy tych skał są scementowane chalkopirytem oraz hematytem.

Noryt rozpoznano w masywach Nyud oraz Poaz (próbki 32, 33 oraz 35). Tło skały stanowią tabliczki plagioklazów o strukturze ofitowej (ryc. 4D). Towarzyszą im duże kryształy ortopiroksenów o obłych kształtach. Są one niekiedy spękane, a na ich granicach jest widoczny talk oraz serpentyn. W ich sąsiedztwie mogą występować niewielkie kryształki zserpentynizowanego oliwinu oraz pojedyncze klinopiroksenów. Ziarna klinopiroksenów są nieregularne, ksenomorficzne, gdyż krystalizują w przestrzeniach pomiędzy minerałami maficznymi. Akcesorycznie występują biotyt, ilmenit, pentlandyt, apatyt, a także cyrkon, chloroapatyt i fluoryt.

Gabronoryt występuje w masywie Nyud, w strefie przejściowej pomiędzy perydotytem a ortopiroksenitem (próbki 28 i 30). Skała ta towarzyszy także norytowi w masywie Poaz (próbka 34). Tło skalne gabronorytu tworzą tabliczki plagioklazów o strukturze ofitowej (ryc. 4E). Plagioklazy te sa polisyntetycznie zbliźniaczone. Obok nich są widoczne duże, obłe kryształy ortopiroksenu, często spękane, z talkiem oraz serpentynem w strefach granicznych. Niekiedy towarzyszą im pojedyncze blaszki flogopitu. Oprócz tych minerałów występują klinopirokseny. Ich kryształy osiagają rozmiar $1 \mathrm{~cm}$ i są silnie postrzępione. Spajają one kryształy ortopiroksenów i występują pomiędzy plagioklazami. Towarzyszą im aktynolit i epidot oraz relikty niewielkich, drobnych kryształów oliwinu. W skale tej obserwowano ilmenit i magnetyt. Ponadto w rejonie kontaktu ze skałami tzw. krytycznego horyzontu Nyud (czyli miejsca iniekcji pierwotnych stopów w zastygające skały plutonu) występuje okruszcowany gabronoryt (próbka 30) z widocznymi siarczkami, reprezentowanymi przez chalkopiryt, piryt, pirotyn i pentlandyt.
Zsaussurytyzowane gabro (próbka 26) występuje w masywie Nyud. Skała ta składa się z dużych, ksenomorficznych, silnie postrzępionych kryształów klinopiroksenów, wielkości do kilku mm. Są w niej widoczne plagioklazy, serycyt, chloryt i hornblenda zwyczajna. Niekiedy można dostrzec także niewielkie osobniki prehnitu oraz agregaty rudne $z$ tremolitem i epidotem. W skale tej odznaczają się strefy z kataklazą minerałów.

Zamfibolityzowany gabronoryt (próbka 27) towarzyszy zsaussurytyzowanemu gabru w masywie Nyud. Tło tej skały wypełnia ksenomorficzny ortopiroksen: skataklazowany, postrzępiony, ulegający uralityzacji. W jego sąsiedztwie obserwowano kryształy hornblendy, tremolitu, aktynolitu, biotytu, epidotu i chlorytu (ryc. 4E). Stwierdzono także pojedyncze osobniki rutylu, ilmenitu oraz tytanitu. W masywie Vurechuaivench skałom tym towarzyszą także zamfibolityzowane anortozyty (próbka 36), w których obok hornblendy zwyczajnej i tytanitu znajdują się relikty klinopiroksenu z dużą ilością plagioklazów.

\section{Charakterystyka minerałów skałotwórczych}

Oliwin w skałach ultrazasadowych intruzji Monczegorska tworzy zwykle duże, obłe kryształy, niekiedy zdeformowane mechanicznie. W skałach tych w strefach wtórnie przeobrażonych jest zserpentynizowany (ryc. 5A-C), a wokół jego kryształów rozwijają się korony reakcyjne, złożone z serpentynitu, talku, tremolitu, rzadziej flogopitu. W gabrach oliwin jest raczej rzadkim minerałem akcesorycznym. Procesy wtórne wpływają na kształt kryształów oliwinu. W skałach ultrazasadowych są ne zwykle izometryczne, obłe, w skałach objętych procesami wtórnymi ich kontury są mocno postrzępione.

Ortopirokseny w skałach ultrazasadowych są zwykle izometryczne, obłe, lecz w zależności od rodzaju skały moga mieć ściany wklęsłe lub wypukłe. W niektórych kumulatach tworzą duże kryształy, których rozmiary dochodzą do $1 \mathrm{~cm}$, czasem są zdeformowane. W gabroidach najczęściej noszą ślady daleko posuniętych procesów wtórnych - bywają zuralityzowane i zserpentynizowane (ryc. 5D-F).

Klinopirokseny są rzadko spotykane w utworach ultrazasadowych, występują w nich akcesorycznie i zwykle mają silnie zmienione, postrzępione kontury ziaren. W gabroidach mogą występować zarówno jako minerał tła skalnego (gabra, gabronoryty), jak i w formie akcesorycznej, a nawet reliktowej (metaanortozyty; ryc. 5G-I).

Plagioklazy w skałach ultrazasadowych zwykle stanowią niewielką domieszkę minerałów krystalizujących w przestrzeniach pomiędzy fazami maficznymi. W gabrach jest ich znacznie więcej, zwykle są wykształcone w formie tabliczek i tworzą tło skały o strukturze ofitowej (ryc. 5J-L).

\section{Wyniki analiz fraktalnych}

Większy wymiar fraktalny (ok. 1,8) mają mocno skorodowane oliwiny pochodzące $\mathrm{z}$ tzw. krytycznego horyzontu w skałach masywu Nyud oraz z bloku dunitowego, gdzie są one mocno zserpentynizowane. Mniejszym wymiarem fraktalnym (ok. 1,3) cechują się oliwiny z masywów Nittis 


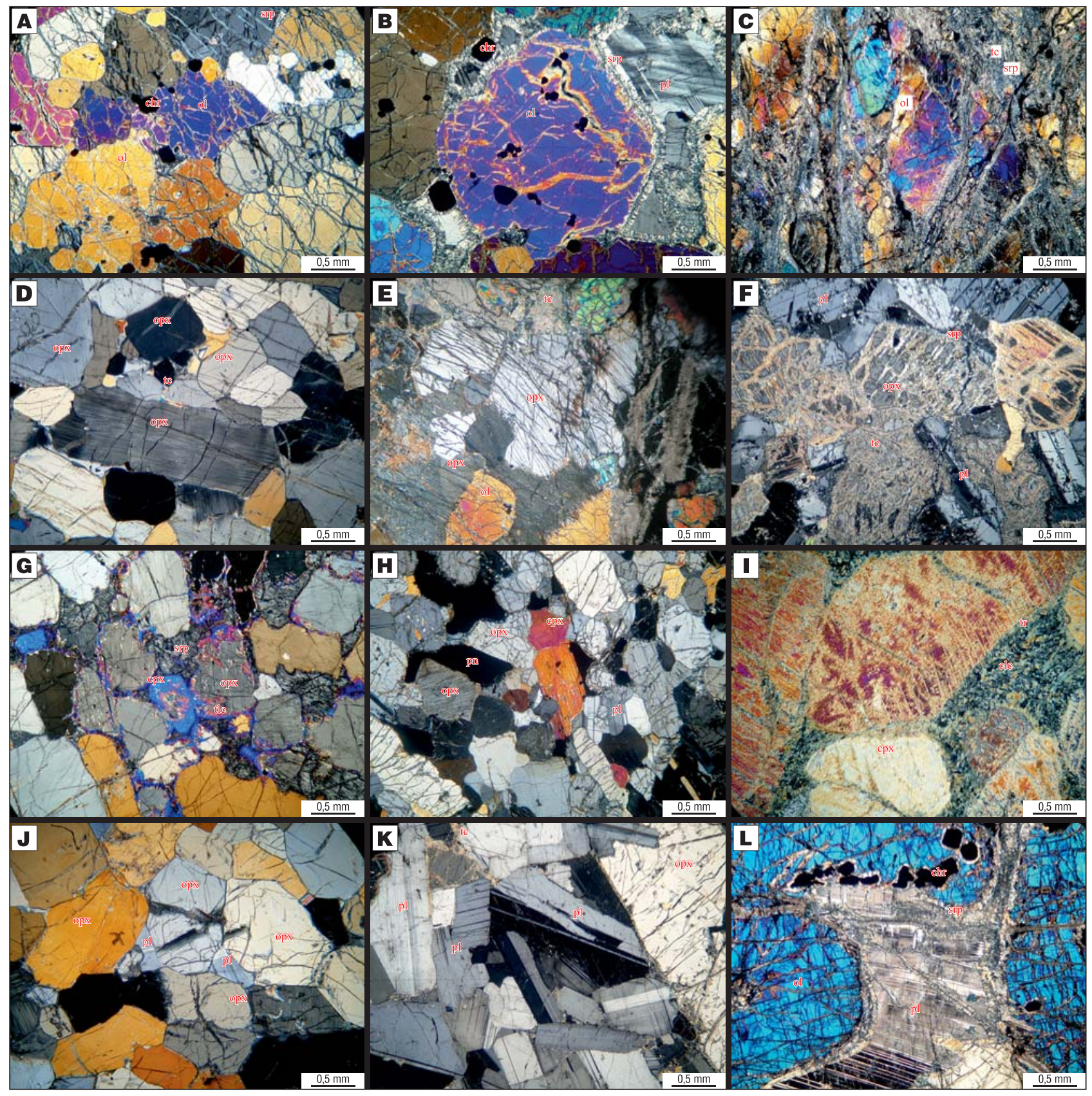

Ryc. 5. Zróżnicowanie kształtu ziaren oliwinu (A-C), ortopiroksenów (D-F), klinopiroksenów (G-I) i plagioklazów (J-L) w skałach intruzji Monczegorska: A - oliwiny w dunicie, B - euhedralny kryształ oliwinu w harzburgicie; C - rozlasowany oliwin w zmyllonityzyowanym perydotycie; D - ortopiroksen w ortopiroksenicie; $\mathbf{E}$ - ortopiroksen w harzburgicie; $\mathbf{F}$ - skorodowany ortopiroksen w norycie; $\mathbf{G}$ - klinopiroksen w ortopiroksenicie; $\mathbf{H}$ - klinopiroksen w norycie; $\mathbf{I}$ - klinopiroksen w zsaussurytyzowanym gabrze; J plagioklaz w ortopiroksenicie; $\mathbf{K}$ - plagioklaz w norycie; $\mathbf{L}$ - plagioklaz w plagioharzburgicie

Fig. 5. Different shapes of olivine $(\mathbf{A}-\mathbf{C})$, orthopyroxene $(\mathbf{D}-\mathbf{F})$, clinopyroxene $(\mathbf{G}-\mathbf{I})$ and plagioclase $(\mathbf{J}-\mathbf{L})$ in the rocks of the Monchepluton: A - olivines in dunite; $\mathbf{B}$ - euhedral olivine crystal in harzburgite; $\mathbf{C}$ - melted olivine in mylllonitized peridotite; $\mathbf{D}$ - orthopyroxene in orthopyroxenite; $\mathbf{E}$ - orthopyroxene in harzburgite; $\mathbf{F}$ - corroded orthopyroxene in norite; $\mathbf{G}$ - clinopyroxene in orthopyroxenite; $\mathbf{H}$ - clinopyroxene in norite; $\mathbf{I}$ - clinopyroxene in ssaussuritised gabbro; $\mathbf{J}$ - plagioclase in orthopyroxenite; $\mathbf{K}$ - plagioclase in norite; $\mathbf{L}$ - plagioclase in plagioharzburgite

i Kumuzhia (ryc. 6A; tab. 2). Analizując zróżnicowanie wymiaru fraktalnego badanych ziaren ortopiroksenów, stwierdzono, że mniejszy wymiar mają ziarna pochodzące z masywu Kumuzhia, bloku dunitowego, masywu Sopcha i krytycznego horyzontu w Nyud (1,3), a większy ze skał masywów Nittis, Poaz oraz północnej części masywu Traviannaya (1,8; ryc. 6B). Klinopirokseny charakteryzują się dużym zróżnicowaniem wymiaru fraktalnego (ryc. 6C; tab. 2) - najmniejszy wymiar mają minerały z zachodniej i północnej części masywu Sopcha oraz masywu Poaz. Nieco większy wymiar mają klinopirokseny w masywie Kumuzhia, a największy z masywów Nittis, Traviannaya oraz Sopcha i Nyud. Plagioklazy (ryc. 6B), cechujące się największym wymiarem fraktalnym, pochodziły z bloku dunitowego, masywu Kumuzhia, a także przełęczy Nyud oraz masywów Nyud i Poaz. Mniejszym wymiarem charakteryzują się plagioklazy z masywów Vurechuaivench oraz Traviannaya (tab. 2). 
Tab. 2. Uśrednione wymiary fraktalne minerałów skałotwórczych w próbkach skał z intruzji Monczegorska Table 2. Averaged fractal dimensions of rock-forming minerals in rock samples from the Monchepluton

\begin{tabular}{|c|c|c|c|c|c|c|}
\hline $\begin{array}{l}\text { Masyw } \\
\text { Massif }\end{array}$ & $\begin{array}{l}\text { Próbka } \\
\text { Sample }\end{array}$ & $\begin{array}{l}\text { Skala } \\
\text { Rock }\end{array}$ & $\begin{array}{l}\text { Oliwin } \\
\text { Olivine }\end{array}$ & $\begin{array}{c}\text { Klinopirokseny } \\
\text { Clinopyroxene }\end{array}$ & $\begin{array}{l}\text { Ortopirokseny } \\
\text { Orthopyroxene }\end{array}$ & $\begin{array}{l}\text { Plagioklazy } \\
\text { Plagioclase }\end{array}$ \\
\hline \multirow[t]{6}{*}{ Traviannaya } & 1 & oliwinowy ortopiroksenit / olivine orthopyroxenite & 1,63 & & & \\
\hline & 2 & plagioharzburgit / plagioharzburgite & & & 1,51 & 1,5 \\
\hline & 3 & oliwinowy plagiowebsteryt / olivine plagiowebsterite & & 1,64 & & 1,49 \\
\hline & 4 & masywny ortopiroksenit / massive orthopyroxenite & & 1,63 & & 1,25 \\
\hline & 5 & masywny ortopiroksenit / massive orthopyroxenite & 1,83 & 1,53 & 1,83 & 1,43 \\
\hline & 6 & oliwinowy plagiowebsteryt / olivine plagiowebsterite & 1,5 & 1,7 & 1,76 & 1,57 \\
\hline \multirow[t]{3}{*}{ Kumuzhia } & 7 & oliwinowy ortopiroksenit / olivine orthopyroxenite & 1,37 & 1,34 & & \\
\hline & 8 & oliwinowy ortopiroksenit / olivine orthopyroxenite & & & & \\
\hline & 9 & oliwinowy harzburgit / olivine harzburgite & & & 1,52 & 1,36 \\
\hline \multirow[t]{2}{*}{ Nittis } & 10 & oliwinowy ortopiroksenit / olivine orthopyroxenite & 1,33 & 1,32 & 1,53 & 1,44 \\
\hline & 11 & plagioortopiroksenit / plagioorthopyroxenite & 1,48 & 1,37 & 1,67 & 1,45 \\
\hline \multirow{4}{*}{$\begin{array}{l}\text { blok dunitowy } \\
\text { Dunite Block }\end{array}$} & 12 & chromityt / chromitite & 1,59 & 1,78 & & \\
\hline & 13 & dunit / dunite & & & & \\
\hline & 14 & plagioharzburgit / plagioharzburgite & 1,42 & & & \\
\hline & 15 & oliwinowy gabronoryt / olivine gabbronorite & & 1,43 & 1,6 & 1,42 \\
\hline \multirow[t]{10}{*}{ Sopcha } & 16 & harzburgit / harzburgite & 1,53 & 1,34 & 1,67 & 1,57 \\
\hline & 17 & masywny ortopiroksenit / massive orthopyroxenite & & 1,32 & & 1,7 \\
\hline & 18 & oliwinowy ortopiroksenit / olivine orthopyroxenite & & & 1,7 & \\
\hline & 19 & oliwinowy ortopiroksenit / olivine orthopyroxenite & 1,44 & 1,46 & 1,5 & 1,45 \\
\hline & 20 & masywny ortopiroksenit / massive orthopyroxenite & & 1,37 & & \\
\hline & 21 & harzburgit / harzburgite & 1,57 & & 1,33 & 1,68 \\
\hline & 22 & harzburgit / harzburgite & 1,56 & 1,45 & 1,75 & \\
\hline & 23 & oliwinowy ortopiroksenit / olivine orthopyroxenite & 1,4 & 1,35 & 1,6 & 1,63 \\
\hline & 24 & ortopiroksenit / orthopyroxenite & & & & \\
\hline & 25 & harzburgit / harzburgite & 1,39 & 1,45 & 1,62 & 1,72 \\
\hline \multirow{2}{*}{$\begin{array}{l}\text { Nyud } \\
\text { - anomalia }\end{array}$} & 26 & zsaussurytyzowane gabro / ssaussuritised gabbro & & 1,8 & 1,53 & 1,54 \\
\hline & 27 & zamfibolityzowany gabronoryt / amphibolised gabbronorite & & & 1,47 & \\
\hline \multirow[t]{6}{*}{ Nyud } & 28 & gabronoryt / gabbronorite & 1,45 & 1,51 & 1,66 & 1,38 \\
\hline & 29 & plagioharzburgit / plagioharzburgite & 1,53 & 1,36 & 1,53 & 1,65 \\
\hline & 30 & gabronoryt / gabbronorite & & 1,37 & 1,49 & 1,46 \\
\hline & 31 & harzburgit / harzburgite & 1,57 & 1,59 & 1,59 & 1,55 \\
\hline & 32 & noryt / norite & & 1,54 & 1,67 & 1,54 \\
\hline & 33 & noryt / norite & & 1,48 & 1,73 & 1,63 \\
\hline \multirow[t]{2}{*}{ Poaz } & 34 & gabronoryt / gabbronorite & & 1,46 & 1,68 & 1,36 \\
\hline & 35 & noryt / norite & & 2,02 & 1,37 & 1,53 \\
\hline Vurechuaivench & 36 & zamfibolityzowany anortozyt / amphibolised gabbronorite & & & 1,51 & 1,63 \\
\hline
\end{tabular}

\section{DYSKUSJA}

Na podstawie analizy wymiarów fraktalnych oliwinów z intruzji Monczegorska oraz ich cech tekstualnych obserwowanych w płytkach cienkich, stwierdzono, że istnieje pewna korelacja pomiędzy wymiarem fraktalnym a genezą minerału i jego późniejszą historią geologiczną. W skałach ultrazasadowych oliwiny przyjmują zwykle formę izometryczną, jednak często ulegają korozji, przez co mają silnie rozczłonkowane granice i większy wymiar fraktalny. Ortopirokseny powinny mieć mały wymiar fraktalny, jednak ich ziarna w skałach z masywów Nittis oraz Traviannaya mają duże wymiary fraktalne, uwarunkowane zapewne przez procesy wtórne (ryc. 6B). W gabroidach masywów Nyud i Poaz, a także w rejonie tzw. anomalii, ortopirokseny podlegały korozji. Podobne przemiany nastapily w klinopiroksenach (ryc. 6C). W masywach Traviannaya i Sopcha klinopirokseny występują głównie jako minerały krystalizujące w interstycjach ortopiroksenów, dlatego ich wymiary fraktalne są duże. W masywach Nyud i Poaz klinopirokseny podlegały korozji. W gabroidach masywu Poaz są one stosukowo najmniej skorodowane i izometryczne. W zachodniej części masywu Sopcha, gdzie ziarna klinopiroksenów mają niewielki wymiar fraktalny, znajdują się websteryty, w których minerały te mają kształt zbliżony do euhedralnego. Korelacja wymiaru fraktalnego ziaren 
plagioklazów (ryc. 6B) z ich genezą i późniejszymi przemianami jest bardzo skomplikowana. W masywie Traviannaya ziarna plagioklazów występują akcesorycznie w plagioharzburgitach; w masywie Nittis wykrystalizowały w interstycjach ortopiroksenów i mają urozmaicony kształt; we wschodnich masywach są zwykle wykształcone w formie tabliczkowej, co nie powinno zwiększać ich wymiaru fraktalnego, podlegały natomiast serycytyzacji.

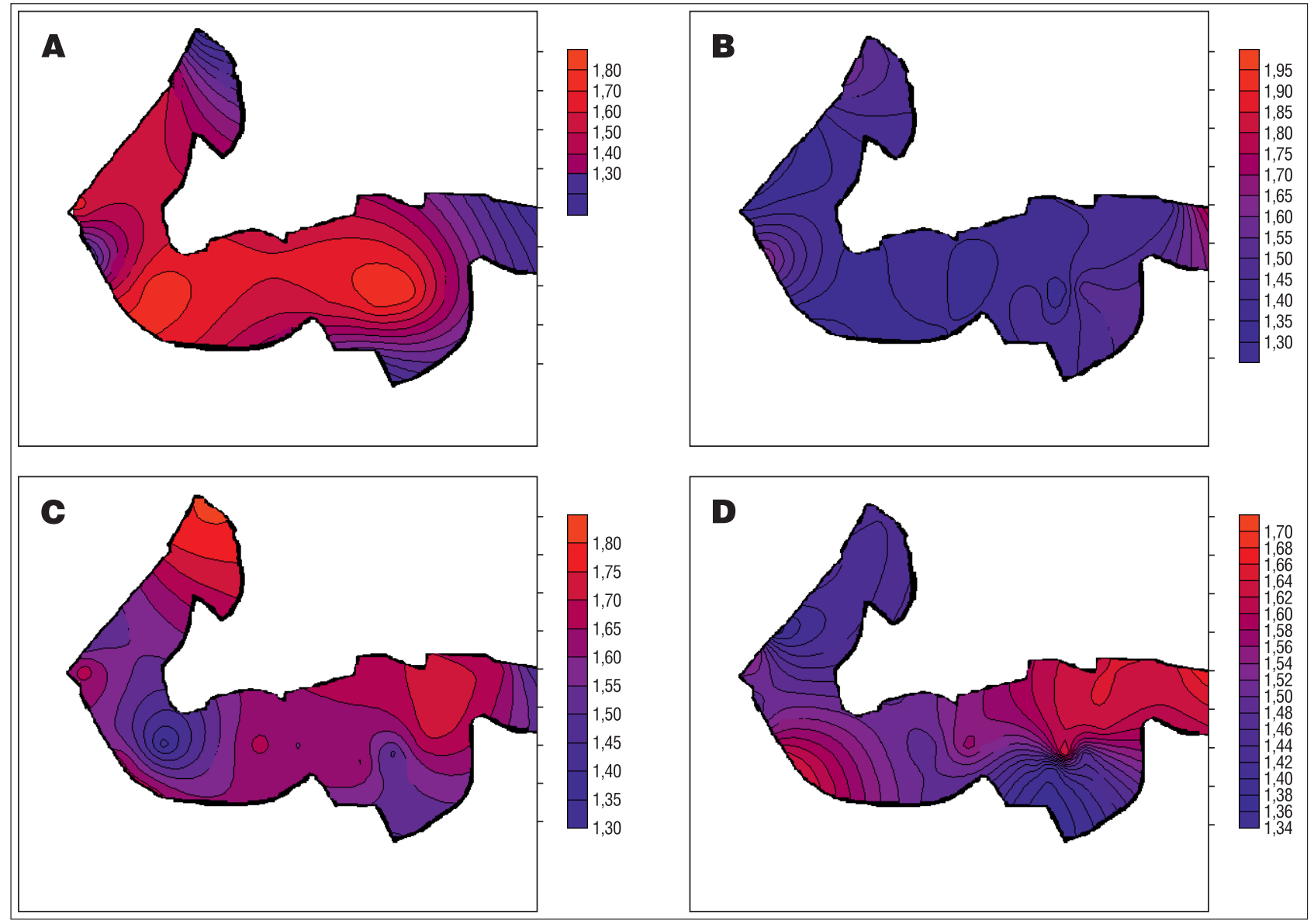

Ryc. 6. Mapy rozkładu wymiaru fraktalnego: A - oliwinów, B - plagioklazów, C - ortopiroksenu i D - klinopiroksenu Ryc. 6. Maps of fractal dimension distribution for: $\mathbf{A}$ - olivines, $\mathbf{B}$ - plagioclases, $\mathbf{C}$ - orthopyroxene and $\mathbf{D}$ - clinopyroxene

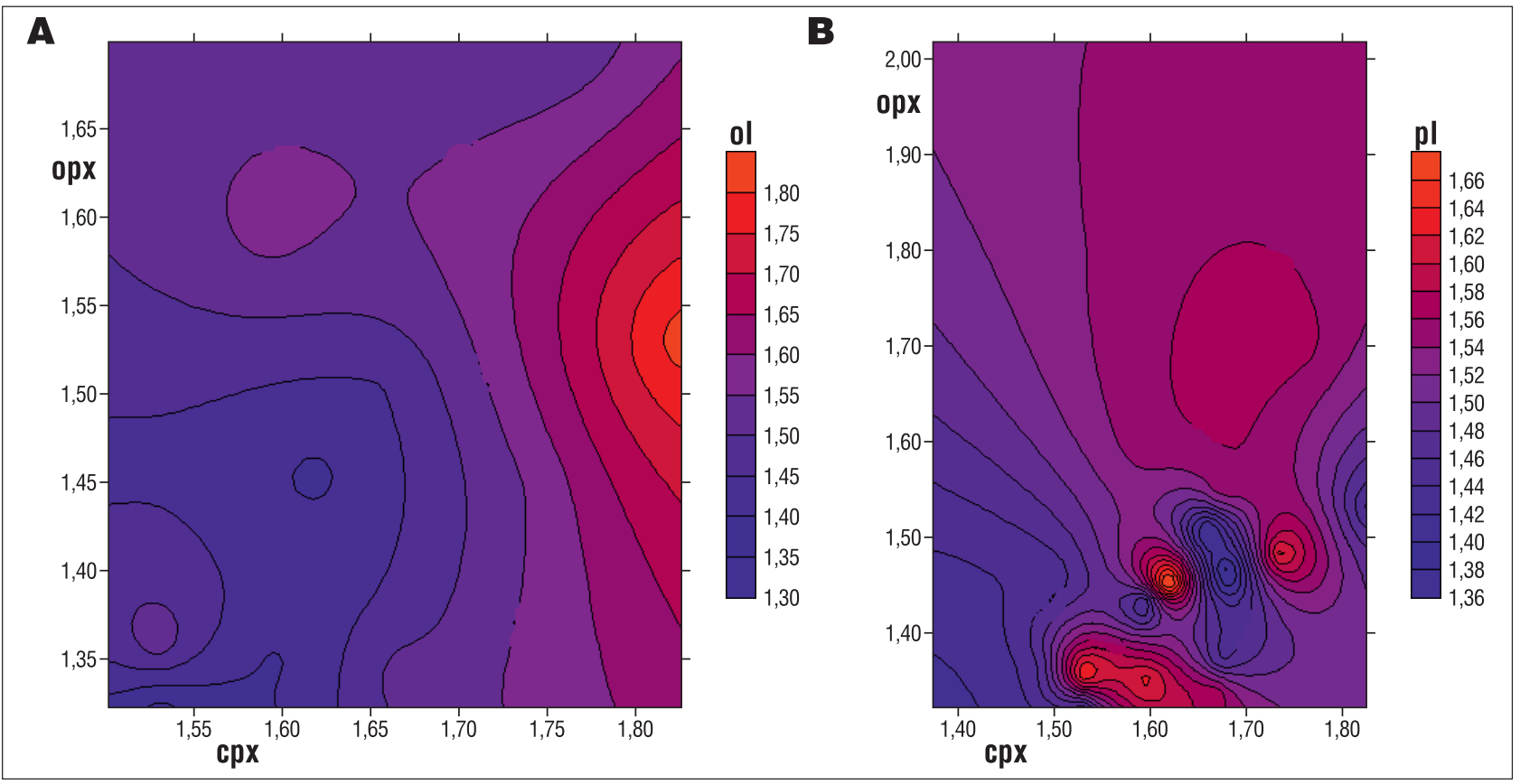

Ryc. 7. Korelacja wymiaru fraktalnego ortopiroksenów, klinopiroksenów, oliwinów i plagioklazów z intruzji Monczegorska Ryc. 7. Correlation of the fractal coefficient for orthopiroxenes, clinopyroxenes, olivines and Monchepluton plagioclases 
Próba korelacji wymiaru fraktalnego konturów minerałów z procesami geologicznymi, jakim one podlegały, wymaga bardzo ostrożnej interpretacji (ryc. 7A). W skałach intruzji Monczegorska największymi wymiarami fraktalnymi odznaczają się ziarna oliwinów i klinopiroksenów, a nieco mniejszymi ziarna ortopiroksenów. Taki wynik może obrazować częstą obecność klinopiroksenów w skałach, w których oliwin uległ procesom wtórnym, oraz to, że ortopirokseny są w tym układzie trwalsze i rzadziej ulegaja korozji. Duży wymiar fraktalny konturów ziaren klinopiroksenów jest też zapewne skutkiem tego, że krystalizowały one w interstycjach pomiędzy innymi minerałami i na skutek tego ich ziarna przyjęly skomplikowany, nieregularny kształt. Nie dotyczy to klinopiroksenów w gabroidach, gdzie współwystępują one z ortopiroksenami, tworząc kryształy izometryczne. Na diagramie ukazującym korelację współczynnika fraktalnego plagioklazów z orto- i klinopiroksenami (ryc. 7B) można zauważyć, że jest ona silnie zaburzona. W miejscach, gdzie zwiększa się wymiar fraktalny konturu ziaren klinopiroksenów, wymiar fraktalny ziaren plagioklazów raz rośnie, a raz maleje. Można to thumaczyć tym, że w skałach ultrazasadowych plagioklazy występują w postaci pojedynczych tabliczek, a klinopirokseny są w nich niekiedy minerałem akcesorycznym. Interesujące jest także to, że tam gdzie zwiększa się wymiar fraktalny ortopiroksenów, wzrasta także wymiar fraktalny plagioklazów (ryc. 7B).

\section{KONKLUZJE}

W zasadowych i ultrazasadowych skałach intruzji Monczegorska można dostrzec skutki oddziaływania różnych procesów wtórnych, jakim podlegały jej poszczególne masywy - m.in. korozji, deformacjom sieciowym, serpentynizacji i serycytyzacji. Efektem tych procesów jest współczesny skład petrograficzny skał intruzji oraz kształt ich minerałów skałotwórczych. Niestety, analiza wymiaru fraktalnego minerałów w skałach intruzji Monczegorska doprowadziła jedynie do takiego wniosku, że nie można tego wymiaru jednoznacznie powiązać z żadnym $\mathrm{z}$ rozpoznanych procesów, jakim były poddane analizowane minerały. Powoduje to problem $\mathrm{w}$ interpretacji otrzymanych wyników, które w bardzo ograniczonym zakresie ilustrują zmiany zachodzace $w$ minerałach pod wpływem procesów geologicznych i mogą być wykorzystywane tylko jako forma dopełniająca klasyczny opis skał. Próby korelacji wymiarów fraktalnych różnych minerałów nastręczyły jeszcze większych trudności interpretacyjnych i na tak przedstawionym etapie badań stanowią materiał naukowy bardzo ograniczony jakościowo.

\section{LITERATURA}

ARZAMASTSEV A.A., FEDOTOV Z.A., ARZAMASTSEVA L.V. 2009 - Daikovyi magmatizm severo-vostochnoi chasti Baltiiskogo shchita. St. Petersburg Nauka: 383.

BALTYBAEV S.K. 2013 - Svecofennian Orogen of the Fennoscandian Shield: Compositional and Isotopic Zoning and its Tectonic Interpretation. Geotectonics, 47 (6): 452-464.

BALUEV A.S., ZHURAVLEV V.A., PRZHIYALGOVSKII E.S. 2009

New Data on the Structure of the Central Part of the White Sea Paleorift System. Doklady Earth Sci., 427 (6): 891-896.

BAYANOVA T.B. 2004 - Age of benchmark geological complexes of the Kola region and magmatism processes action. St. Petersburg Nauka: 174 BAYANOVA T., KORCHAGIN A., MITROFANOV A., SEROV P., EKIMOVA N., NITKINA E., KAMENSKY I., ELIZAROV D., HUBER M. 2019 - Long-Lived Mantle Plume and Polyphase Evolution of Palaeo- proterozoic PGE Intrusions in the Fennoscandian Shield. Minerals, 9 (59): 3-22.

CHEN T.L., SHI Z.L., WEN A., YAN D., GOU J., CHEN J., LIU Y, CHEN R. 2021 - Multifractal characteristics and spatial variability of soil particle-size distribution in different land use patterns in a small catchment of the Three Gorges Reservoir Region. China. J. Mt. Sci., 18 (1): $111-125$

GERIG A., KRUHL J.H., CAGGIANELLI A. 2010 - Quantification of Flow Patterns in Sheared Tonalite Crystal-melt Mush: Application of Fractal-geometry Methods. J. Geol. Soc. India, 75: 210-224.

GULBIN Y.L., EVANGULOVA E.B. 2003 - Morphometry of Quartz Aggregates in Granites: Fractal Images Referring to Nucleation and Growth Processes. Mathemat. Geol., 35 (7): 819-833.

HAŁAS S., HUBER M., PIESTRZYŃSKI A. 2009 - Petrology of gabbroid and isotope signature of sulfide mineralization from Fedorov-Pansky layered mafic intrusion, Kola Peninsula, Russia. Geochronometria 33: 19-22.

HUBER M. 2012 - Dynamics of metamorphism processes by the fractal textures analysis of garnets, amphibole and pyroxenes of Lapland Granulite Belt, Kola Peninsula. J. Biol. Earth Sci., 2: 50-55.

HUBER M. 2021 - Ewolucja kolsko-laplandzkiego pasa mobilnego na przykładzie platynonośnej paleoproterozoicznej intruzji warstwowanej Moncheplutonu. Wyd. UMCS.

HUBER M., HAŁAS S., SEROV P.A., EKIMOVA N.A., BAYANOVA T.B. 2012 - Sm-Nd dating and stable isotope geochemistry of sulfides and $\mathrm{U}-\mathrm{Pb}$ ages of layered intrusions from the northern part of the Baltic Shield. Mineralogia, 39: 107.

KINCAL C., KOCA M.Y., OZDEN G., DEMIRBASA N. 2010 - Fractal parameter approach on weathering grade determination of Cesme (Izmir, Turkey) tuffs. Bull. Eng. Geol. Environ., 69: 617-629.

LEHMANN P., STAHLA M., PAPRITZ A., GYGI A., FLUHER H. 2003

- A Fractal Approach to Model Soil Structure and to Calculate Thermal Conductivity of Soils. Transport in Porous Media, 52: 313-332.

LUBNINA N.V., PASENKO A.M., NOVIKOVA M.A., BUBNOV A.YU.

2016 - The East European Craton at the End of the Paleoproterozoic: a New Paleomagnetic Pole of 1.79-1.75 Ga. Moscow Univ. Geol. Bull., $71(1): 8-17$.

MARTIN M.A., REYES M. 2008 - A Fractal Interaction Model for Winding Paths through Complex Distributions: Application to Soil Drainage Networks. Pure Appl. Geophys., 165: 1153-1165.

MITROFANOV A.F. 2000 - Geological characteristics of the Kola peninsula. Russian Acad. Sci., Apatity: 166.

MITROFANOV F.P., SMOLKIN V.F. 2004 - Stratified intrusions of the Monchegorsk ore region: petrology, mineralization, isotopy, deep structure. In 2 parts. Ed. Apatity: Kola Scientific Center, Russian Acad. Sci.: 344. MOHAMMADI A., KHAKZAD A., OMRAN N.R., MAHVI M.R., MOAREFVAND P., AFZAL P. 2013 - Application of number-size (N-S) fractal model for separation of mineralized zones in Dareh-Ashki gold deposit, Muteh Complex, Central Iran. Arab J. Geosci., 6: 4387-4398. MIYASHIRO A. 1994 - Metam. Petrol., CRC Press: 416.

PETIGEN H.O., JÜRGENS H., SAUPE D. 1992 - Fractals for the Classroom. Springer-Verlag N.Y., 1: 546.

POZHYLIENKO V.I., GAVRILIENKO B.V., ZHIROV D.V., ZHABIN S.V. 2002 - Geology of the ore regions in Murmańsk District. Apatity: 360. RUNDKVIST T.V., MOKRUSHIN A.V., HUBER M., PRIPACHKIN P.V., BAZAI A.V., MIROSHNIKOVA YA.A. 2018 - New data on the composition of chrome spinellids in the rocks of the southeastern of the Early Proterozoic Monchegorsk complex (Kola region). Bull. of the Kola Scientific Center of the Russian Acad. Sci., 1 (10): 50-62, DOI: 10.25702/KSC.2307-5228-2018-10-1-50-62 (po rosyjsku).

SHARKOV E.V. 2006 - Formation of Layered Intrusions and their ore mineralization. Moscov Scientific World: 368.

SINGH A.K., UPADHYAY D., PRUSETH K.L., MEZGER K., NANDA J.K., MAITI S., SAHA D. 2021 - Shock Metamorphic Features in the Archean Simlipal Complex, Singhbhum Craton, Eastern India: Possible Remnant of a Large Impact Structure. J. Geol. Soc. India, 97: 35-47.

SŁABY E., DOMONIK A., ŚMIGIELSKI M., MAJZNER K., MOTUZA G., GOETZE J., SIMON K., MOSZUMAŃSKA I., KRUSZEWSKI Ł., RYDELEK P. 2014 - Protomylonite evolution potentially revealed by the 3D depiction and fractal analysis of chemical data from a feldspar. Contrib Mineral Petrol, 167: 995.

VOITSEKHOVSKY Y.L., SHPACHENKO A.K., SKIBA V.I. 1997 Cell-zonal textures of tinguaites from the Kola Peninsula. Geol. Rundsch., 86: 531-538.

ZHERU Z., HUAHI M., CHENG Q. 2001 - Fractal Geometry of Element Distribution on Mineral Surfaces. Mathem. Geol., 33 (2): 217-228. ZHENGLI M., JIANQING L., YANG B. 2014 - The geochemical multi-fractal characteristics and mineralization of the Dehelongwa copper-gold deposit. Chin. J. Geochem, 33: 280-288.

Praca wpłynęła do redakcji 22.04.2021 r.

Akceptowano do druku 17.05.2021 r. 